\title{
The expression of the SCD1 gene and its correlation with fattening and carcass traits in sheep
}

\author{
K. Ropka-Molik ${ }^{1}$, J. Knapik ${ }^{2}$, M. Pieszka ${ }^{3}$, and T. Szmatoła ${ }^{1}$ \\ ${ }^{1}$ Department of Genomics and Animal Molecular Biology, National Research Institute of \\ Animal Production, 32-083 Balice, Poland \\ ${ }^{2}$ Department of Animal Genetics and Breeding, National Research Institute of \\ Animal Production, 32-083 Balice, Poland \\ ${ }^{3}$ Department of Animal Nutrition and Feed Science, National Research Institute of \\ Animal Production, 32-083 Balice, Poland \\ Correspondence to: K. Ropka-Molik (katarzyna.ropka@izoo.krakow.pl)
}

Received: 5 August 2015 - Revised: 21 December 2015 - Accepted: 15 January 2016 - Published: 25 January 2016

\begin{abstract}
Stearoyl-CoA desaturase 1 (SCD1) is a critical enzyme that catalyzes the synthesis of monounsaturated fatty acids and is involved in several signaling pathways related to lipid metabolism. The objective of the present study was to estimate the expression of the SCD1 gene in three different ovine tissues strongly associated with lipid homeostasis. The SCD1 gene expression measurement was performed on three tissues (liver, subcutaneous fat, perirenal fat) originated from 15 old-type Polish Merino sheep. The SCD1 transcript abundance was evaluated based on the two most stable endogenous controls (RPS2 - ribosomal protein S2; ATP5G2 - H(+)transporting ATP synthase). The highest expression of the SCD1 gene was observed in ovine subcutaneous fat compared to perirenal fat and liver. Furthermore, the present research indicated the significant correlation between ovine SCD1 transcript abundance and several important production traits. The expression of the SCD1 gene in liver and perirenal fat highly positively correlated with the feed : gain ratio, test of daily gain and age of the animals at slaughter. Moreover, in both tissues, the SCD1mRNA level positively correlated with weight and content of perirenal fat and subcutaneous fat $(R=0.64,0.8,0.6$, respectively) and negatively with assessment of external fat content with the use of the EUROP scale $(R=-0.64)$. The SCD1 expression in subcutaneous fat also corresponds with back fat of blade chop and thickness of longissimus dorsi muscles evaluated using USG (ultrasonography) ( $R=-0.6$ and 0.62 , respectively). The significant correlation between SCD1 transcript abundance and fattening and slaughtering traits indicate the ability to improve important production traits in sheep via modification of expression of the SCD1 gene.
\end{abstract}

\section{Introduction}

The main factors determining quality and health-promoting properties of meat are fat content and fatty acid composition (Wood et al., 2004). The most desirable is a low content of saturated fatty acid in the meat while also maintaining the proper ratio of polyunsaturated fatty acids (PUFAs) to saturated fatty acids (SFAs) $(P / S)$. Stearoyl-CoA desaturase 1 (SCD1) is a critical enzyme that catalyzes the synthesis of monounsaturated fatty acids (MUFAs; palmitoleyl-CoA and oleyl-CoA), which are the key components of triglyc- erides and membrane phospholipids. By modifying the ratio of MUFAs to SFAs, SCD1 enzyme effects membrane fluidity, the composition of cholesterol esters and triglycerides which can affect lipoprotein metabolism and adiposity (Ntambi et al., 2002).

The expression of the SCD1 gene is regulated by several hormones, including leptin (Mauvoisin et al., 2010; Mauvoisin and Mounier, 2011), insulin (Mounier and Posner, 2006), ghrelin (Ambati et al., 2009), GH hormone and different growth factors (PDGF, EGF, KGF, FGF) (Mason et al., 2003). Through involvement in many signaling pathways re- 
lated to lipid metabolism, the SCD1 gene is considered a potential factor influencing body weight and obesity (Dobrzyn et al., 2005; Biddinger et al., 2006).

In cattle, the SCD1 gene was significantly associated with MUFA content of marbling fat (Taniguchi et al., 2004) and milk production traits (fat and protein content, milk yield) (Macciotta et al., 2008). In sheep, polymorphisms in SCD1 locus were related to milk fatty acid composition: lactose, stearic, polyunsaturated, and conjugated linoleic fatty acid contents (Zidi et al., 2010). In pigs, polymorphism within the $3^{\prime}$ untranslated region of the SCD1 gene was significantly associated with PUFA, $n-6: n-3$ FA ratio, intramuscular fat content and expression level of the stearoyl-CoA desaturase gene (Lim et al., 2015). Furthermore, the ability of nutrient factors to regulate SCD1 gene expression in farm animals introduced gene encoding SCD1 as one of the candidate genes affecting fatness traits (Costa et al., 2013a; Zhang et al., 2015). The objective of the present study was to estimate the transcript abundance of the SCD1 gene in three different ovine tissues strongly associated with lipid homeostasis. The obtained results showed how to improve important production traits in sheep via modification of expression of the SCD1 gene.

\section{Material and method}

\subsection{Animals and tissues}

The analysis was performed in total on 15 samples from each tissue - liver and fat (subcutaneous fat, perirenal fat) - obtained from old-type Polish Merino sheep. The Polish Merino is a dual-purpose type of sheep, producing both meat and wool. All animals (male) were maintained under the same feeding and housing conditions in the Experimental Station of the National Research Institute of Animal Production in Pawłowice. Sheep were fed ad libitum with complete pelleted fodder with the following nutritive values per kilogram of fodder (according to the INRA system): UFV - $0.81 \mathrm{~g}$; PDIN $-119 \mathrm{~g}$; PDIE - $106 \mathrm{~g}$. To balance dietary fiber, animals received meadow hay as a supplement $\left(100 \mathrm{~g} \mathrm{head}^{-1} \mathrm{day}^{-1}\right)$. Animals were fattened to a final body weight of $40-42 \mathrm{~kg}$, slaughter and dissected. The carcasses were split into half-carcasses and cuts, and the cuts were subjected to detailed dissection according to updated NRIAP procedures at the Experimental Station of the National Research Institute of Animal Production (2009). The parameters measured on individual sheep during the test were the feed : gain ratio $\left(\mathrm{g} \mathrm{kg}^{-1}\right)$, test of daily gain $\left(\mathrm{g} \mathrm{day}^{-1}\right)$, number of days on test (day) and age at slaughter. USG (ultrasonography) measurements were made on living animals on the right side, perpendicular to the spine, just under the last thoracic vertebra.

\subsection{RNA isolation and reverse transcription}

The tissue samples were collected immediately after slaughter into tubes with RNAlater ${ }^{\circledR}$ solution (Ambion, Life Technology) and stored at $-20^{\circ} \mathrm{C}$. Isolation of total RNA was carried out using a PureLink ${ }^{\mathrm{TM}}$ RNA Mini Kit (Ambion, Life Technology) according to the protocol. Quantitative and qualitative analysis of the isolated ribonucleic acid was performed using a NanoDrop 2000 spectrophotometer (Thermo Scientific, Wilmington, USA) and on $2 \%$ agarose gel (Table S1 in the Supplement). A total of $250 \mathrm{ng}$ of total RNA was used to obtain cDNA in $50{ }^{\circ} \mathrm{C}$ using a Maxima First Strand cDNA Synthesis Kit for RT-qPCR (Thermo Scientific) according to the attached protocol.

\subsection{Selection of the stable housekeeping genes}

The normalization of stability of candidate reference genes was performed on eight samples from each tissue - liver and fat (subcutaneous fat, perirenal fat). Eight candidate reference genes were tested - GAPDH, 18s ribosomal RNA, ATP5G2, B2M, RPS2, ACTB, RPL19, and RPS26 (geNorm reference gene selection kit, sheep; PrimerDesign, Southampton, UK). Relative quantification of the mRNA abundance of genes studied was performed with a 7500 RealTime PCR system (Applied Biosystems, Life Technologies). The reaction for each sample was performed in three replicates and in accordance with AmpliQ 5x HOT EvaGreen qPCR Mix protocol (Novazym, Poland). The efficiency of real-time PCR reactions was defined by using the standard curve method $\left(E=\right.$ efficiency $\left(10-1\right.$ slope $\left.^{-1}\right)$; slope - the directional factor of the curve) (Table S2). The standard curve contained three serial dilutions of cDNA $(1 / 10 ; 1 / 100$; $1 / 1000)$ and non-diluted cDNA. The cDNA used to standard curve preparation was obtained by pooling of cDNA samples from three investigated tissues (for three samples from each tissue).

The standard curve was prepared for each analyzed gene. The relative transcript abundance was calculated by using the $\Delta \Delta \mathrm{Ct}$ method according to the $1 / E^{(\mathrm{Ct})}$ formula, where the $\mathrm{Ct}$ value was a cycle determined by the threshold applied to the maximum amplification of the standard curve. In order to identify the most stable reference genes and normalization factor (NF), the geNorm software was used (Vandesompele et al., 2002).

\subsection{Quantification of the SCD1 expression}

The SCD1 transcript abundance was estimated for 15 animals. Primers and probes for the SCD1 gene were designed using Primer Express 3.0 software and synthesized commercially (Applied Biosystems), while the two most stable endogenous controls (RPS2 - ribosomal protein S2; ATP5G2 - H(+)-transporting ATP synthase) were synthetized by PrimerDesign (custom-designed real-time PCR assay with double-dye probe, primer-limited concentration) (Table 1). 
Table 1. Sequences of primers, probes, and PCR efficiencies of the investigated genes and endogenous controls.

\begin{tabular}{|c|c|c|c|c|c|c|c|}
\hline $\begin{array}{l}\text { Gene } \\
\text { symbol }\end{array}$ & Gene name & $\begin{array}{l}\text { GenBank } \\
\text { Accession no. }\end{array}$ & Primer sequence & $\begin{array}{l}\text { Probe sequence } \\
\text { (MGB) }\end{array}$ & Label & $\begin{array}{l}\text { Amplicon } \\
\text { length (bp) }\end{array}$ & $\begin{array}{l}\text { PCR } \\
\text { efficiency }\end{array}$ \\
\hline SCD1 & $\begin{array}{l}\text { Stearoyl- } \\
\text { Coenzyme } \\
\text { Adesaturaze } 1\end{array}$ & FJ513370.1 & $\begin{array}{l}\text { FTTCCAGATCTCTAGCT } \\
\text { CCTACACAAC } \\
\text { R CAATTTGCCCCCTCCATTCT }\end{array}$ & CACCATCACAGCACCT & FAM & 86 & 1.92 \\
\hline ATP5G2 & $\begin{array}{l}\mathrm{H}(+)- \\
\text { transporting } \\
\text { ATP synthase }\end{array}$ & NM_001009468 & $\begin{array}{l}\text { Custom real-time PCR assays with } \\
\text { double-dye probe (Taqman style) - } \\
\text { F ACCACCTCACTGACTCCTAG } \\
\text { R CCCAAACACGGTCCCAATT }\end{array}$ & $\begin{array}{l}\text { VIC equivalent labeled } \\
\text { PrimerDesign Ltd. }\end{array}$ & VIC & 141 & 2.00 \\
\hline RPS2 & $\begin{array}{l}\text { Rybosomal } \\
\text { protein S2 } \\
\text { mRNA }\end{array}$ & DQ520732 & $\begin{array}{l}\text { Custom real-time PCR assays with } \\
\text { double-dye probe (Taqman style) - } \\
\text { F CAGGTTCAAGGCGTTTGTTG } \\
\text { R ATGGCAGTGGCTACTTCCT }\end{array}$ & $\begin{array}{l}\text { VIC equivalent labeled } \\
\text { - PrimerDesign Ltd. } \\
\text { G }\end{array}$ & VIC & 87 & 1.97 \\
\hline
\end{tabular}

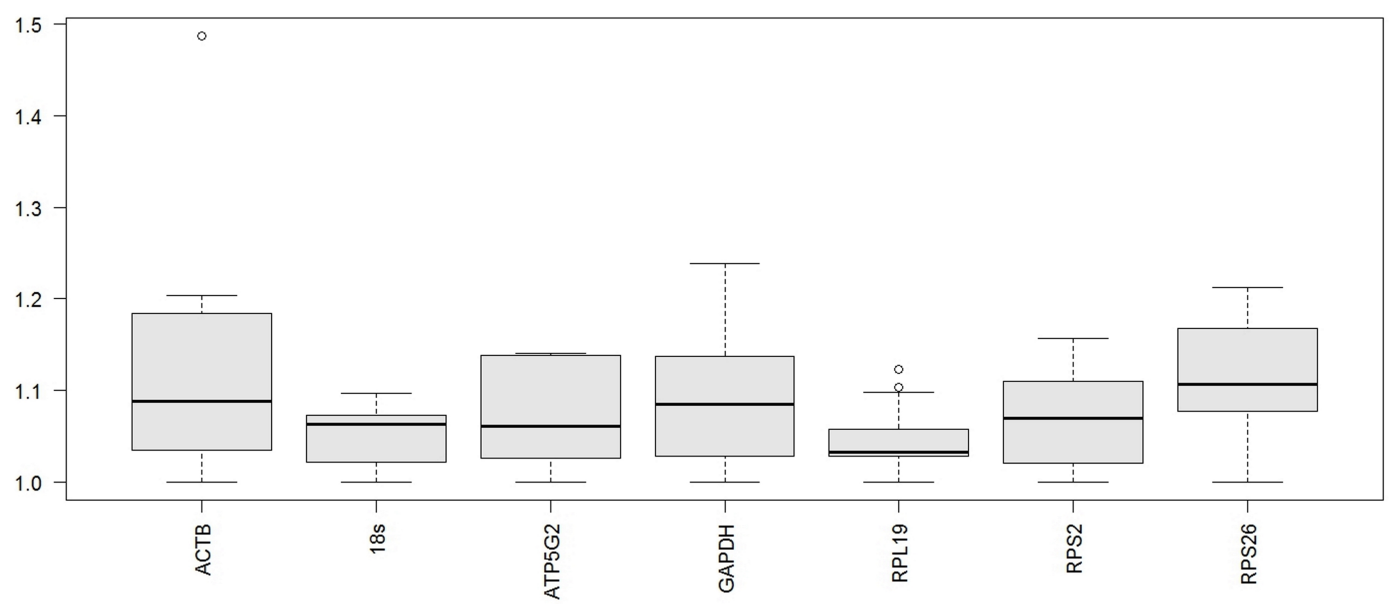

Figure 1. Box plots of qPCR results of all investigated reference genes. The normalized expression levels are displayed on the $y$ axis.

Reaction (in a total volume of $25 \mu \mathrm{L}$ ) was performed in three repeats, in the multiplex for SCD1 and RPS2, separately for ATP5G2 and in accordance with the TaqMan ${ }^{\circledR}$ Gene Expression Master Mix protocol (Applied Biosystems). The relative quantity of SCD1 transcript abundance was calculated using the $\Delta \Delta \mathrm{Ct}$ method and according to Pfaffl (2001). Due to the use of two reference genes the normalization factors (NF) were obtained based on the geometric mean of the normalized quantity of both control genes.

\subsection{Statistical analysis}

The normality of the distribution of analyzed gene expression data was assessed by using Kolmogorov-Smirnov test (SAS v. 8.02). The differences in SCD1 expression levels between tissues were analyzed using Kruskal-Wallis test. The correlation coefficients for fattening and slaughter traits were calculated by using Pearson's correlation and for carcass evaluation traits by Spearman's rank correlation (SAS v. 8.02).

\section{Results}

\subsection{Selection of endogenous control}

The stability of all analyzed reference genes was determined by calculating the geNorm $M$ value for each gene ( $M-$ the average expression stability value). According to the geNorm software, the most stable endogenous genes across analyzed tissues were the RPS2 (average gene expression stability $M=0.08)$ and ATP5G2 $(M=0.5)$ genes. The highest $M$ was obtained for RPL19 $(M=1.64)$ and ACTB $(M=1.82)$ (Table S2). qPCR results are presented in Fig. 1. The $V$ value (pairwise variations) for two the most stable genes (RPS2 and ATP5G2) was 0.027 across all three tissues. The analysis conducted separately for each tissue confirmed that the most stable gene was RPS2 in all tissues.

\subsection{Expression of the ovine SCD1 gene and its correlation with carcass traits}

In the present study, the highest expression of the SCD1 gene was observed in subcutaneous fat compared to perirenal fat and liver $(P \leq 0.01)$. The differences between transcript 
Table 2. Characteristic of the important fattening and slaughter traits in old-type Polish Merino sheep.

\begin{tabular}{lccccc}
\hline Trait & Mean & SD & Min & Max & CV (\%) \\
\hline age at slaughter & 158 & 13.9 & 127 & 173 & 8.92 \\
feed : gain ratio $\left(\mathrm{g} \mathrm{kg}^{-1}\right)$ & 4.44 & 0.5 & 3.31 & 5.21 & 10.16 \\
test of daily gain $\left(\mathrm{g} \mathrm{day}^{-1}\right)$ & 356.1 & 36.2 & 279.2 & 406.3 & 11.26 \\
weight of fat in the half-carcass $(\mathrm{kg})$ & 1.34 & 0.38 & 0.92 & 1.86 & 28.35 \\
fat content in half-carcasses (\%) & 14.42 & 2.35 & 9.89 & 19.18 & 16.29 \\
weight of perirenal fat (kg) & 0.105 & 0.031 & 0.06 & 0.16 & 29.52 \\
back fat of blade chop (kg) & 0.03 & 0.01 & 0.02 & 0.05 & 33.33 \\
back fat of shoulder $(\mathrm{kg})$ & 0.238 & 0.044 & 0.135 & 0.305 & 18.48 \\
fat of breast (kg) & 0.25 & 0.078 & 0.13 & 0.43 & 31.2 \\
thickness of longissimus dorsi muscle mea- & 2.71 & 0.17 & 2.4 & 3.06 & 6.27 \\
sured using USG (cm) & & & & & \\
thickness of external fat measured using & 0.26 & 0.03 & 0.21 & 0.32 & 11.54 \\
USG (cm) & & & & & \\
\hline
\end{tabular}

Carcasses evaluation

\begin{tabular}{lllll}
\hline subcutaneous fat (1-9 point scale) & 6.36 & 0.49 & 6 & 7 \\
$\begin{array}{l}\text { perirenal fat (1-9 point scale) } \\
\begin{array}{l}\text { assessment of external fat on } \\
\text { a EUROP scale (1-5 point) }\end{array}\end{array}$ & 6.45 & 0.74 & 5 & 8 \\
\hline
\end{tabular}

$\mathrm{SD}$ - standard deviation; $\mathrm{CV}$ - coefficient of variation (\%)

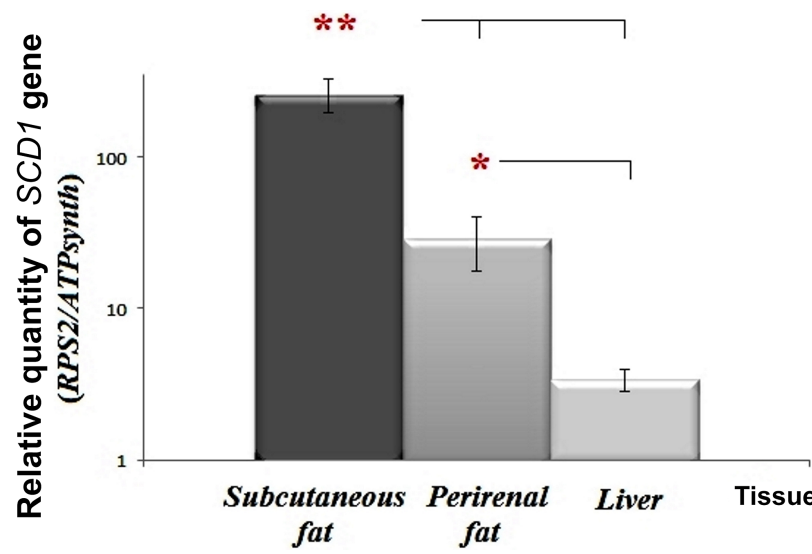

Figure 2. The relative quantity (RQ) of the ovine SCD1 gene in three tissues evaluated based on two endogenous controls (RPS2 and ATP5G2 genes). Data are presented as means \pm standard error $(*-P \leq 0.05 ; * *-P \leq 0.01)$.

abundance obtained in perirenal fat and liver were also significant $(P \leq 0.05)$ (Fig. 2).

The highest $\mathrm{CV}$ values for evaluated production traits were obtained for fatness traits: weight of fat in the half-carcass, weight of perirenal fat, back fat of blade chop ( $\mathrm{CV}$ values $28.35 ; 29.52 ; 33.33 \%$, respectively). This indicated a possibility to improve the level of carcass and individual cuts' fatness by selection. The basic statistical characteristic of important analyzed production traits are shown in Table 2.
The significant correlation coefficient between SCD1 expression level and fattening and carcasses features was obtained for several traits (Table 3). The amount of SCD1 transcript in liver and perirenal fat positively correlated with feed gain ratio, age at slaughter and test of daily gain $(P \leq 0.05)$. For subcutaneous fat the opposite trend was indicated, significant only for test of daily gain. Furthermore, according to Spearman's rank correlation, expression of the SCD1 gene in subcutaneous fat was negatively correlated with external fatness of carcass and perirenal fat content (both evaluated on a 1-9 point scale) $(P \leq 0.05)$. Conversely, positive correlation of these parameters was confirmed for SCD1 mRNA level in liver and perirenal fat (Table 3). The SCD1 expression in subcutaneous fat also corresponds to back fat of blade chop and thickness of longissimus dorsi muscles evaluated using USG ( $R=-0.6$ and 0.62 , respectively).

\section{Discussion}

Health-promoting properties of lamb meat can be adjusted, among other things, by modifying fatty acid profile, in particular by maintaining the proper ratio of PUFAs to SFAs and by increasing the content of omega-3 fatty acids and conjugated linoleic acid (CLA). Generally, the most important goals in this regard are to reduce the amount of medium-chain SFAs and to increase the content of PUFAs and oleic acid (cis-9 $\mathrm{C}-18: 1)$ in the diet so as to reduce the risk of cardiovascular diseases (Kritchevsky et al., 2000; Steinhart et al., 2003).

One of the most essential enzymes which participates in the biosynthesis of MUFA from SFA is SCD1. The SCD1 protein plays a key role in lipid metabolism, and due to 
Table 3. Correlation coefficient between SCD1 transcript abundance and sheep production traits.

\begin{tabular}{|c|c|c|c|c|c|c|}
\hline \multirow[b]{2}{*}{ Trait } & \multicolumn{6}{|c|}{ Transcript abundance of SCD1 gene } \\
\hline & liver & & subcutaneous fat & & perirenal fat & \\
\hline \multicolumn{7}{|l|}{ Fattening traits } \\
\hline age at slaughter & 0.66 & $*$ & -0.47 & & 0.63 & $*$ \\
\hline feed: gain ratio $\left(\mathrm{g} \mathrm{kg}^{-1}\right)$ & 0.7 & $*$ & -0.39 & & 0.59 & $*$ \\
\hline test of daily gain $\left(\mathrm{g} \mathrm{day}^{-1}\right)$ & 0.68 & $*$ & -0.63 & $*$ & 0.55 & $*$ \\
\hline \multicolumn{7}{|l|}{ Slaughter traits } \\
\hline weight of fat in the half-carcass (kg) & 0.35 & & -0.35 & & 0.14 & \\
\hline fat content in half-carcasses (\%) & 0.41 & & -0.35 & & 0.2 & \\
\hline weight of perirenal fat $(\mathrm{kg})$ & 0.64 & $*$ & -0.42 & & 0.31 & \\
\hline back fat of blade chop (kg) & 0.39 & & -0.6 & $*$ & 0.41 & \\
\hline back fat of shoulder $(\mathrm{kg})$ & 0.18 & & -0.33 & & 0.01 & \\
\hline fat of breast $(\mathrm{kg})$ & 0.32 & & -0.44 & & 0.15 & \\
\hline thickness of longissimus dorsi muscle & & & & & & \\
\hline measured using USG $(\mathrm{cm})$ & -0.2 & & 0.62 & $*$ & -0.1 & \\
\hline thickness of external fat measured using USG $(\mathrm{cm})$ & 0.44 & & 0.2 & & 0.34 & \\
\hline \multicolumn{7}{|l|}{ Carcass evaluation } \\
\hline subcutaneous fat (1-9 point scale) & 0.6 & $*$ & -0.57 & $*$ & 0.75 & $* *$ \\
\hline perirenal fat (1-9 point scale) & 0.8 & $* *$ & -0.47 & $*$ & 0.61 & $*$ \\
\hline assessment of external fat on a EUROP scale (1-5 point) & -0.64 & $*$ & 0.24 & & -0.45 & \\
\hline
\end{tabular}

$*-P \leq 0.05 ; * *-P \leq 0.01$.

its function, gene encoding SCD1 has been investigated in humans, mice and farm animals. The highest expression of this gene was observed in adipose tissue (external fat), liver, heart, kidney, lungs and the mammary gland. In most of these tissues/organs, the transcript level for the SCD1 gene rapidly increases in response to a high-carbohydrate diet (Miyazaki et al., 2001, 2002). The present research showed the highest expression of the SCD1 gene in ovine subcutaneous fat compared to perirenal fat and liver. Adipose tissue is considered a critical endocrine organ which acts on the hypothalamus to regulate food intake and energy expenditure via synthesis and secretion of numerous proteins (Henry and Clark, 2008). The high expression of the SCD1 gene in subcutaneous fat obtained in the present study may indicate high secretory activity of white adipocyte tissues and confirm its important role in lipid metabolism. The research performed on SCD1 knockout mice showed that SCD1 may be a global regulator of energy metabolism (Cohen et al., 2002). However, the exact mechanism by which SCD1 affects lipid and energy metabolisms is not well known. According to the fact that expression of the SCD1 gene and protein activity is suppressed by leptin, it is suggested that SCD1 mediates many of leptin's functions (Biddinger et al., 2006). Furthermore, SCD1 regulates the transcriptional activity of several genes involved in fatty acid oxidation (FIAF, FAS, ACO, VLCAD, CPT-1 and GPAT) (Ntambi et al., 2002).
Recent research has shown that SCD1 gene expression can be regulated nutrigenomically. Ntambi (1999) and Ntambi et al. (2004) showed that a diet rich in polyunsaturated fatty acids and cholesterol has a significant effect on the SCD1 gene expression in mice. In addition, the amount of SCD1 mRNA depends on factors such as age and concentration of insulin (Daniel et al., 2004), glucose (Jones et al., 1998) or CLA (Choi et al., 2000). In our research, significant correlation between ovine SCD1 transcript abundance and several important production traits was observed. Interesting results have been obtained for fattening traits, where expression of gene encoding SCD1 in liver and perirenal fat highly significantly correlated with feed: gain ratio, test of daily gain and age of the animals at slaughter. Moreover, in both tissues, SCD1 transcript abundance positively correlated with weight of perirenal fat, with two parameters describing external fatness and content of perirenal fat $(R=0.64,0.6,0.8$, respectively) and negatively with assessment of external fat content by using EUROP scale $(R=-0.64)$. On the other hand, the opposite trend for subcutaneous fat, negative correlation with external fatness and perirenal fat content, was observed. In cattle, Costa et al. (2013b) showed positive correlation between transcript abundance of SCD and the ratios of $18: 1 \mathrm{c} 9$ and c9, t11-CLA in subcutaneous adipose tissue. Some authors have also obtained negative correlation between SCD expression and 16:0 content as well as SFA level. Likewise, in pigs, Bessa et al. (2013) confirmed positive association be- 
tween SCD protein level in muscle tissue and MUFA and total muscle fatty acid content. In liver and fat tissues, SCD1 is the main enzyme which indicates the conversion of the SFAs to MUFAs. The above results confirm an important role of liver and fat in the regulation of food intake, fat metabolism and homeostasis. The opposite correlation coefficients, between SCD1 expression and fatness traits, obtained for subcutaneous and perirenal fat may indicate differences in function and metabolic activity of both tissues. The obtained results may be related to differences in saturated and unsaturated fatty acid ratio in these fat tissues. It has also been reported that, in sheep during fetal development, perirenal fat contains brown adipocytes with numerous mitochondria and plays a critical role in lipid metabolism (Bernard et al., 1999). Furthermore, Doran et al. (2006) showed that the modification of diet affects SCD1 transcript level in muscle and fat tissues in a different way. The authors suggested that tissuespecific expression of SCD1 resulted from different regulatory mechanism occur in both tissues, which may partially explain the results obtained in the present study. Recent studies performed on cattle tissues (liver, lung, muscle) by Rezamand et al. (2014) confirmed that correlation between gene expression and SCD1 protein level is also tissue-specific.

The results obtained in the present research suggested that the modification of SCD1 expression (e.g., by nutrigenomic modification) would affect important production traits in sheep such as feed conversion efficiency or carcass fatness. Jiang et al. (2008) showed that activity of stearoyl-CoA desaturase and SNPs within the cattle SCD1 gene were positively correlated with marbling score and amount of MUFA and CLA but negatively with amount of SFA. Moreover, studies with cattle showed that polymorphisms within the SCD1 gene and the level of its expression are associated with the deposition of fatty acids in the muscles and milk (Castillo et al., 2010). In pigs, Estany et al. (2014) indicated that polymorphism located in the promoter region enhanced fat desaturation, but without affecting fat content in muscle. In the present study, high coefficient of variation values obtained for several fatness traits indicated a possibility to improve these characteristics by selection. The above results indicate the need to search for the causative mutation which would affect the expression of the SCD1 gene.

\section{Conclusion}

Our study provides two novel housekeeping genes for normalization of the expression experiments in different ovine tissues. We show that the most stable reference genes in liver and fat tissues were RPS2 and ATP5G2. Our research confirms that expression of the SCD1 gene is strongly related to the tissue type, and the highest mRNA level was observed in subcutaneous fat. The significant correlation between SCD1 transcript abundance and several ovine fattening and slaughtering traits indicates the ability to improve important pro- duction traits in sheep via modification of expression of the SCD1 gene. The opposite correlation coefficients obtained between expression of SCD1 in subcutaneous and perirenal fat and production features may confirm different functions and metabolic activity of both fat tissues.

\section{The Supplement related to this article is available online at doi:10.5194/aab-2-37-2016-supplement.}

Acknowledgements. This study was supported by the National Research Institute of Animal Production statutory activity, research project no. 01-4.05.1.

Edited by: S. Maak

Reviewed by: two anonymous referees

\section{References}

Ambati, S., Li, Q., Rayalam, S., Hartzell, D. L., Della-Fera, M. A., Hamrick, M. W., and Baile, C. A.: Central leptin versus ghrelin: effects on bone marrow adiposity and gene expression, Endocrine, 37, 115-123, 2009.

Bernard, S. J., Yuen, I., McMillen, C., Symonds, M. E., and Owens, P. C.: Abundance of leptin mRNA in fetal adipose tissue is related to fetal body weight, J. Endocrinol., 163, R1-R4, 1999.

Bessa, R. J. B., Hughes, R. A., Jeronimo, E., Moreira, O. C., Prates, J. A. M., and Doran, O.: Effect of pig breed and dietary protein level on selected fatty acids and stearoyl-coenzyme A desaturase protein expression in longissimus muscle and subcutaneous fat, J. Anim. Sci., 91, 4540-4546, 2013.

Biddinger, S. B., Miyazaki, M., Boucher, J., Ntambi, J. M., and Kahn, C. R.: Leptin suppresses stearoyl-CoA desaturase 1 by mechanisms independent of insulin and sterol regulatory element-binding protein-1c, Diabetes, 55, 2032-2041, 2006.

Castillo, J. A., Pabon, M. L., Olivera, M., and Carulla, J. E.: Role of stearoyl CoA desaturase on conjugated Linoleic acid concentration in bovine milk: review, Rev. Colomb. Cienc. Pec., 23, 493500, 2010.

Choi, Y., Kim, Y. C., Han, Y. B., Park, Y., Pariza, M. W., and Ntambi, J. M.: The trans-10, cis-12 isomer of conjugated linoleic acid downregulates stearoyl-CoA desaturase 1 gene expression in 3T3-L1 adipocytes, J. Nutr., 130, 1920-1924, 2000.

Cohen, P., Miyazaki, M., Socci, N. D., Hagge-Greenberg, A., Liedtke, W., Soukas, A. A., Sharma, R., Hudgins, L. C., Ntambi, J. M., and Friedman, J. M.: Role for stearoyl-CoA desaturase-1 in leptin-mediated weight loss, Science, 297, 240-243, 2002.

Costa, A. S. H., Pires, V. M., Fontes, C. M., and Mestre Prates, J. A.: Expression of genes controlling fat deposition in two genetically diverse beef cattle breeds fed high or low silage diets, BMC Vet. Res., 9, 1-16, doi:10.1186/1746-6148-9-118, 2013a.

Costa, A. S. H, Silva, M. P., Alfaia, C. P. M., Pires, V. M. R., Fontes, C. M. G. A., Bessa, R. J. B., and Prates, J. A. M.: Genetic Background and Diet Impact Beef Fatty Acid Composition and Stearoyl-CoA Desaturase mRNA Expression, Lipids, 48, 369381, 2013b. 
Daniel, Z. C. T. R., Richards, S. E., Salter, A. M., and Buttery, J. P.: Insulin and dexamethasone regulate stearoyl-CoA desaturase mRNA levels and fatty acid synthesis in ovine adipose tissue explants, J. Anim. Sci., 82, 231-237, 2004.

Dobrzyn, A., Dobrzyn, P., Lee, S. H., Miyazaki, M., Cohen, P., Asilmaz, E., Hardie, D. G., Friedman, J. M., and Ntambi, J. M.: Stearoyl-CoA desaturase-1 deficiency reduces ceramide synthesis by downregulating serine palmitoyltransferase and increasing beta-oxidation in skeletal muscle, Am. J. Physiol.-Endoc. M., 288, E599-E607, 2005.

Doran, O., Moule, S. K., Teye, G. A., Whittington, F. M., Hallett, K. G., and Wood, J. D.: A reduced protein diet induces stearoylCoA desaturase protein expression in pig muscle but not in subcutaneous adipose tissue: relationship with intramuscular lipid formation, Brit. J. Nutr., 95, 609-617, 2006.

Estany, J., Ros-Freixedes, R., Tor, M., and Pena, R. N.: A functional variant in the stearoyl-CoA desaturase gene promoter enhances fatty acid desaturation in pork, PLoS One, 9, e86177, doi:10.1371/journal.pone.0086177, 2014.

Henry, B. A. and Clarke, I. J.: Adipose tissue hormones and the regulation of food intake, J. Neuroendocrinol., 20, 842-849, 2008.

Jiang, Z., Michal, J. J., Tobey, D. J., Daniels, T. F., Rule, D. C., and MacNeil, M. D.: Significant associations of stearoyl-CoA desaturase (SCD1) gene with fat deposition and composition in skeletal muscle, Int. J. Biol. Sci. 4, 345-351, 2008.

Jones, B. H., Standridge, M. K., Claycombe, K. J., Smith, P. J., and Moustaïd-Moussa, N.: Glucose induces expression of stearoylCoA desaturase in 3T3-L1 adipocytes, Biochem. J., 15, 405-408, 1998.

Kritchevsky, D., Tepper, S. A., Wright, S., Tso, P., and Czarnecki, S. K.: Influence of conjugated linoleic acid (CLA) on establishment and progression of atherosclerosis in rabbits, J. Am. Coll. Nutr, 19, 472-477, 2000.

Lim, K. S., Kim, J. M., Lee, E. A., Choe, J. H., and Hong, K. C.: A Candidate Single Nucleotide Polymorphism in the 3' Untranslated Region of Stearoyl-CoA Desaturase Gene for Fatness Quality and the Gene Expression in Berkshire Pigs, Asian-Austral. J. Anim., 28, 151-157, 2015.

Macciotta, N. P. P., Mele, M., Conte, G., Serra, A., Cassandro, M., Zotto, R. D., Borlino, A. C., Pagnacco, G., and Secchiari, P.: Association between a polymorphism at the stearoyl CoA desaturase locus and milk production traits in Italian Holsteins, J. Dairy. Sci., 91, 3184-3189, 2008.

Mason, R. J., Pan, T., Edeen, K. E., Nielsen, L. D., Zhang, F., Longphre, M., Eckart, M. R., and Neben, S.: Keratinocyte growth factor and the transcription factors C/EBP alpha, C/EBP delta, and SREBP-1c regulate fatty acid synthesis in alveolar type II cells, J. Clin. Invest., 112, 244-255, 2003.

Mauvoisin, D. and Mounier, C.: Hormonal and nutritional regulation of SCD1 gene expression, Biochimie, 93, 78-86, 2011.

Mauvoisin, D., Prevost, M., Ducheix, S., Arnaud, M. P., and Mounier, C.: Key role of the ERK1/2 MAPK pathway in the transcriptional regulation of the Stearoyl-CoA Desaturase (SCD1) gene expression in response to leptin, Mol. Cell Endocrinol., 319, 116-128, 2010.

Miyazaki, M., Kim, H. J., Man, W. C., and Ntambi, J. M.: Oleoyl$\mathrm{CoA}$ is the major de novo product of stearoyl-CoA desaturase 1 gene isoform and substrate for the biosynthesis of the Harderian gland 1-alkyl-2,3-diacylglycerol, J. Biol. Chem., 276, 3945539461, 2001

Miyazaki, M., Gomez, F. E., and Ntambi, J. M.: Lack of stearoylCoA desaturase-1 function induces a palmitoyl-CoA Delta6 desaturase and represses the stearoyl-CoA desaturase-3 gene in the preputial glands of the mouse, J. Lipid. Res., 43, 2146-2154, 2002.

Mounier, C. and Posner, B. I.: Transcriptional regulation by insulin: from the receptor to the gene, Can. J. Physiol. Pharm., 84, 713724, 2006.

Ntambi, J. M.: Regulation of stearoyl-CoA desaturase by polyunsaturated fatty acids and cholesterol, J. Lipid. Res., 40, 1549-1558, 1999.

Ntambi, J. M., Miyazaki, M., Stoehr, J. P., Lan, H., Kendziorski, C. M., Yandell, B. S., Song, Y., Cohen, P., Friedman, J. M., and Attie, A. D.: Loss of stearoyl-CoA desaturase-1 function protects mice against adiposity, P. Natl. Acad. Sci. USA, 99, 11482 11486, 2002.

Ntambi, J. M., Miyazaki, M., and Dobrzyn, A.: Regulation of stearoyl-CoA desaturase expression, Lipids, 39, 1061-1065, 2004.

Pfaffl, M. W.: A new mathematical model for relative quantification in real-time RT-PCR, Nucleic. Acids. Res., 29, 2002-2007, doi:10.1093/nar/29.9.e45, 2001.

Rezamand, P., Watts, J. S., Yavah, K. M., Mosley, E. E., Ma, L., Corl, B. A., and McGuire, M. A.: Relationship between stearoylCoA desaturase 1 gene expression, relative protein abundance, and its fatty acid products in bovine tissues, J. Dairy Res., 81, 333-339, 2014.

Steinhart, H., Rickert, R., and Winkler, K.: Identification and analysis of conjugated linoleic acid isomers (CLA), Eur. J. Med., 8, 370-372, 2003.

Taniguchi, M., Utsugi, T., Oyama, K., Manmen, H., Kobayashi, M., Tanabe, Y., Ogino, A., and Tsuji, S.: Genotype of stearoyl-CoA desaturase is associated with fatty acid composition in Japanese black cattle, Mamm. Genome., 14, 142-148, 2004.

Wood, J. D., Richardson, R. I., Nute, G. R., Fisher, A. V., Campo, M. M., Kasapidou, E., Sheard, P. R., and Enser, M.: Effects of fatty acids on meat quality: a review, Meat Sci., 66, 21-32, 2004

Vandesompele, J., De Preter, K., Pattyn, F., Poppe, B., Van Roy, N., De Paepe, A., and Speleman, F.: Accurate normalization of real-time quantitative RT-PCR data by geometric averaging of multiple internal control genes, Genome Biol., 3, 34.1-34.11, doi:10.1186/gb-2002-3-7-research0034, 2002.

Zhang, H., Dong, X., Wang, Z., Zhou, A., Peng, Q., Zou, H., Xue, B., and Wang, L.: Dietary conjugated linoleic acids increase intramuscular fat deposition and decrease subcutaneous fat deposition in Yellow Breed $\times$ Simmental cattle, Anim. Sci. J., doi:10.1111/asj.12447, 2015.

Zidi, A., Fernández-Cabanás, V. M., Urrutia, B., Carrizosa, J., Polvillo, O., González-Redondo, P., Jordana, J., Gallardo, D., Amills, M., and Serradilla, J. M.: Association between the polymorphism of the goat stearoyl-CoA desaturase 1 (SCD1) gene and milk fatty acid composition in Murciano-Granad in a goats, J. Dairy Sci. 93, 4332-4339, 2010. 